3 Wolthers OD, Pedersen S. Controlled study of linear growth in asthmatic children during treatment with inhaled glucocorticosteroids. Pediatrics 1992; 89: 839-42.

4 Hermanussen M, Geiger-Benoit K, Burmeister J, Sippell WG. Knemometry in childhood: accuracy and standardization of Knew technique of lower leg measurement. Ann Hum Biol 1988; 15: 1-16.

5 Wolthers OD, Konstantin-Hansen K, Pedersen S, Petersen $\mathrm{KE}$. Knemometry in the assessment of short term linear KE. Knemometry in the assessment of short term linear growth in a populatio

6 Wolthers OD, Pedersen S. Short term linear growth in asthmatic children during treatment with prednisolone. $B M \mathcal{F} 1990$; 301: 145-8.

7 Harding SM. The human pharmacology of fluticasone propionate. Res Med 1990; suppl A: 25-9.

8 Brown HM, Storey G. Beclomethasone dipropionate steroid aerosol in treatment of perennial allergic asthma in children. BMF 1973; 3: 161-4.

9 Feinstein AR. Clinical biostatistics. St Louis: Mosby, 1977 320-34.

10 Tanner JM. Growth at adolescence. Oxford: Blackwell, 1962.

11 Valk IM, Langhout Chabloz AME, Smals AGH, Kloppenborg PWC, Cassorla FG, Schutte EAST. Accurate measurements of the lower leg length and the ulnar length and its application in short term growth measurement. Growth $1983 ; 47: 53-66$.

12 Wales JKH, Milner RDG. Knemometry in assessment of linear growth. Arch Dis Child 1987; 62: 166-71.

13 Searle SR. Linear models for unbalanced data. New York: Wiley, 1987.

14 Godfrey S, Balfour-Lynn L, Tooley M. A three- to five-year follow-up of the use of the aerosol steroid, beclomethasone dipropionate, in childhood asthma. $\mathcal{F}$ Allergy Clin Immunol 1978; 62: 335-9.

15 Graff-Lonnevig V, Kraepelien S. Long term treatment with beclomethasone dipropionate aerosol in asthmatic children with special reference to growth. Allergy 1979; 34: 57-61.

16 Bahn GL, Gwyn CM, Smith JM. Growth and adrenal function of children on prolonged beclomethasone dipropionate treatment. Lancet 1980; i: 76-7.

17 Balfour-Lynn L. Growth and childhood asthma. Arch Dis Child 1986; 61: 1049-55.

18 Nassif $E$, Weinberger $M$, Sherman B, Brown K. Extrapulmonary effects of maintenance corticosteroid therapy with alternate-day prednisone and inhaled beclomethasone in children with chronic asthma. $\mathcal{F}$ Allergy Clin Immunol 1987; 80: 518-29.

19 Hermanussen M, Geiger-Benoit K, Burmeister J, Sippell WG. Can the knemometer shorten the time for growth rate assessment? Acta Paediatr Scand Suppl 1987; 337: 30-6.

20 Hermanussen $M$, Burmeister I. Standards for the predictive accuracy of short term body height and lower leg length accuracy of short thate 1989; 64: 259-63.

21 Kerrebijn KF, De Kroon JPM. Effect on height of corticosteroid therapy in asthmatic children. Arch Dis Child 1968; 43: $556-61$.

22 Hauspie R, Susanne C, Alexander F. Maturitional delay and temporal growth retardation in asthmatic boys. $\mathcal{F}$ Allergy Clin Immunol 1977; 59: 200-6.

23 Falliers CJ, Szentivanyi J, Mcbride M, Bukantz SC. Growth rate of children with intractable asthma. F Allergy 1961; 32 420-34.

\title{
Umbilical skin
}

Here's something else for you to measure in the newborn. The length of the skin of the umbilicus is slightly ( 2 or $3 \mathrm{~mm}$ ) greater on the cranial surface than on the caudal. A paper from the Mayo clinic (Aengus S O'Marcaigh and colleagues, Pediatrics 1992; 90: 47-9) gives a normal range for cranial surface umbilical skin length measured from the junction of the abdominal wall and umbilicus to the junction of umbilical skin and gelatinous cord with gentle traction on the cord. In 104 babies of between 36 and 43 weeks' gestation and 2235 to $5490 \mathrm{~g}$ birth weight this measurement was not dependant on sex, gestation, weight, or body length. It did, however, slowly decrease between birth and 48 hours of age after which it remained constant up to 90 hours. Mean cranial surface umbilical skin length (95\% confidence intervals) at birth was 13.5 $\mathrm{mm}(7 \cdot 5$ to $20 \cdot 0)$ and at 48 hours $8.7 \mathrm{~mm}(2.5$ to $16 \cdot 0)$.

Why would you wish to measure umbilical skin length? It might help in the diagnosis of several dysmorphic syndromes especially Rieger's syndrome (autosomal dominant, goniodysgenesis, midface hypoplasia, variable hypodontia). Other syndromes with abnormal umbilical morphology include Aarskog's syndrome (X linked recessive, small stature, unusual facies, genital anomalies) and Robinow's syndrome (autosomal dominant, possibly recessive in some, 'fetal face', short forearms, genital hypoplasia, growth deficiency). 